\title{
Hybrid Composites of Poly (diphenylamine sulfonic acid) and nano-Alumina for Impedimetric Humidity Sensors
}

\author{
Şule Dinç Zor, Hüsnü Cankurtaran* \\ Y1ldiz Technical University, Faculty of Science and Arts, Department of Chemistry, \\ 34220 Davutpasa-Istanbul, Turkey \\ *E-mail: husnu3500@yahoo.com
}

doi: $10.20964 / 2017.03 .45$

Received: 24 December 2016 / Accepted: 23 January 2017 / Published: 12 February 2017

\begin{abstract}
In this paper, nano-hybrid composites of water-soluble, conducting polymer poly (diphenylamine sulfonic acid) (PSDA) with nano- $\mathrm{Al}_{2} \mathrm{O}_{3}$ and (3-mercaptopropyl) trimethoxysilane (MPTMS) have been prepared to construct the interdigitated impedimetric type of humidity sensors. Humidity sensing characteristics of the sensors including the sensitivity, hysteresis, response/recovery time, repeatability and long-term stability were investigated. The performances of the studied sensors have been discussed by taking into consideration the film composition and applied alternating current frequency. The best results were obtained for the composite with a weight percentage of $50 \% \mathrm{Al}_{2} \mathrm{O}_{3}$, which exhibits good linearity $\left(R^{2}=0.9949\right)$, high sensitivity (three orders of impedance change), rapid response (55 s and $65 \mathrm{~s}$ at $1 \mathrm{kHz}$ and $100 \mathrm{kHz}$, respectively) and recovery ( $155 \mathrm{~s}$ and $55 \mathrm{~s}$ at $1 \mathrm{kHz}$ and $100 \mathrm{kHz}$, respectively) times, low hysteresis $(<4 \% \mathrm{RH})$, good repeatability (RSD $<1 \%)$ and long-term stability $(\mathrm{RSD}<5 \%)$ in the whole relative humidity range of $10-95 \%$. These results show that PSDAMPTMS- $\mathrm{Al}_{2} \mathrm{O}_{3}$ nanocomposites are promising materials for impedimetric humidity sensors.
\end{abstract}

Keywords: Humidity sensor, poly (diphenylamine sulfonic acid), alumina, nanocomposite, impedance measurement.

\section{$\underline{\text { FULL TEXT }}$}

(C) 2017 The Authors. Published by ESG (www.electrochemsci.org). This article is an open access article distributed under the terms and conditions of the Creative Commons Attribution license (http://creativecommons.org/licenses/by/4.0/). 